8. Fairweather, R. 1998. Sight Records Report. Beaverhill Bird Observatory.

9. Fairweather, R. 1999. Sight Records Report. Beaverhill Bird Observatory.

10. Fisher, C. and J. Acorn. 1998. Birds of Alberta. Lone Pine Publishing, Edmonton.

11. Goossen, J.P., D.M. Ealey, H. Judge, and D.C. Duncan. 1995. Distribution and breeding status of the White-faced Ibis, Plegadis chichi in Canada. Canadian Field Naturalist 109: 391-402.
13. Salt, W.R., and J.R. Salt. The Birds of Alberta. 1976. Hurtig Publishers, Edmonton.

14. Semenchuk, G. 1998. Alberta Breeding Bird Atlas. Federation of Alberta Naturalists, Edmonton.

15. RAMSAR Web site: (http: // environment.harvard.edu / guides / intenvpol / indexes / treaties / RAMSAR.html) accessed on Oct 30 2000.

12. Kardynal, K. and G. Peterson. 2000. Sight Record Report. Beaverhill Bird Observatory.

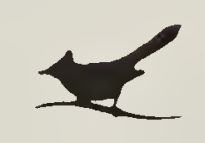

\title{
SLOW NORTHWARD SPREAD OF THE LARK SPARROW
}

C. STUART HOUSTON and MARY I. HOUSTON, 863 University Drive, Saskatoon, SK, S7N 0J8

Walley documented the northward spread of the Lark Sparrow in westcentral Manitoba, citing nest records for Birtle, Riding Mountain National Park, and Dauphin between 1971 and 1993. ${ }^{15}$ In Saskatchewan its northward spread began soon after 1900. These extensions of range were not known to Martin and Parrish, when they compiled the Lark Sparrow account for the Birds of North America series. ${ }^{1}$

Saskatchewan's only two pre- 1900 records of the Lark Sparrow are from the southwest and both by William Spreadborough: a specimen taken at Old Wives Lake on 22 May 1895 and a pair sighted at Sucker Creek near Cypress Lake on 1 July $1895 .{ }^{9}$ Not one was recorded on trips to the Cypress Hills by Bent in 1906 and 1907 , Taverner and Laing in 1921, nor Mitchell in 1917, 1919 and 1921.3, 6 The best early documentation is by Laurence B. Potter in the Frenchman River Valley on the southeast aspect of the Cypress Hills, 5 miles west of Eastend. Prior to 1922, when two pairs took up residence, Potter had a few, short, mid-May visits from Lark Sparrows, although not every year. ${ }^{11}$ In his reminiscences, Potter recounted that "the Lark Sparrow is a striking example of a bird formerly uncommon, that has increased with the settlement of the prairies. ... of late, this sparrow has increased perceptibly and has extended its range. ... [I] discovered a 
nest containing five eggs on June 17 , 1940." 12 By 1946, five pairs were nesting in Charles Holmes' farmyard, 11 miles east of Eastend and six miles north of the Frenchman River. ${ }^{8}$ Farther east, at Indian Head, George Lang saw his first Lark Sparrow in 1913, 26 years after he first settled there. ${ }^{5}$

J. Dewey Soper, in travels across the province from 1927 to 1942 and in 1946, encountered no Lark Sparrows north of the Cypress Hills and Big Muddy Valley (unpublished field notes). Since the 1950s they have been regularly encountered along the length of the South Saskatchewan River and, by the early 1990s, as many as 10 could be found in the extensive campground at Saskatchewan Landing Provincial Park, designated by Stan Shadick as "the Lark Sparrow capital of Saskatchewan."14

The preferred habitat of the Lark Sparrow is "ranchland with scattered trees and bushes, the semi-arid slopes of the South Saskatchewan River valley, and the steep, brushy coulees." 14 Written for the Elbow area, this description is apt throughout southern Saskatchewan. Callin's first sighting in the Qu'Appelle Valley was in 1944; thereafter he found it "rare or uncommon" in the valley and "very rare" in the adjacent parklands. It showed a definite preference for the drier northern valley slopes. ${ }^{5}$ Elsewhere, its sparse distribution includes an occasional farmyard. Frank Roy and Ed Driver in 1992 and 1993 studied 45 deserted farmyards in the Rosetown 1:250,000 map sheet area and found only one Lark Sparrow in 1992, but nine in 1993 (Frank Roy, pers. comm.).

\section{Breeding records beyond the Cypress Hills}

Saskatchewan's first two nests were found within the city limits of Regina in 1936 by Mrs. Elizabeth Flock and by $\mathrm{E}$.
H. M. Knowles. Knowles found another two nests with a single male the next summer. North of Regina, Doug Gilroy found the first nest on his farm along Boggy Creek in 1958. ${ }^{2}$ At Saskatoon, the first nest was found by Jim Slimmon along the river at Tipperary Creek on 27 June 1964. In the Rosetown-Biggar area, a nest with four eggs was found in aspen-covered sand dunes southwest of Harris on 17 June 1973, the first year this species was seen by the Renaud brothers. ${ }^{13}$

The northern-most nest sites in Saskatchewan are within 5 miles of the North Saskatchewan and Saskatchewan valleys. Spencer Sealy found a nest 5 miles south of Battleford, 20 June 1960 , although Fred Bard saw none there during six weeks of field collecting in May and June 1935. ${ }^{1}$ After four decades without seeing or hearing one, Maurice Street found four nests, three above the river valley but within a mile of it, near Nipawin in 1964. ${ }^{15}$ The species did not appear at the farm of Wally Harstad (pers. comm.), southeast of Codette and 6 miles south of the river, until 8 July 1992, and the first nest, with five eggs, was found in his farmyard on 10 June 1999.

The black, white and chestnut facial pattern, with a white crown stripe, together with a single, central breast spot and a long, rounded, black, towhee-like tail, with white corners, differentiate the Lark Sparrow from all other sparrows; indeed, taxonomists place it in its own genus, Chondestes. The song is equally distinctive: a melodious jumble of rich notes and trills, interspersed with harsh buzzes or churrs. Watch and listen for it.

1. Belcher, M. 1972. An early provincial museum field camp in the Battleford area. Blue Jay 30:8-17. 
2. Belcher, M. 1980. Birds of Regina. Special Publication 12, Saskatchewan Natural History Society, Regina.

3. Bent, A.C. 1907-08. Summer birds of southwestern Saskatchewan. Auk 24:407-430 and 25:25-35.

4. Bradshaw, F. 1918, 1920, 1922. Report of the chief game guardian for Saskatchewan.

5. Callin, E.M. 1980. Birds of the Qu'Appelle Valley, 1857 - 1979. Special Publication 13, Saskatchewan Natural History Society, Regina.

6. Godfrey, W.E. 1950. Birds of the Cypress Hills and Flotten Lake regions, Saskatchewan. National Museum of Canada Bull. 120.

7. Godfrey, W.E. 1986. Birds of Canada, revised edition. Ottawa: National Museum of Natural Sciences.

8. Holmes, C.F. 1946. Mockingbird and Lark Sparrow. Blue Jay 4:42.

9. Macoun, J. 1904. Catalogue of Canadian birds, part 3. S.E. Dawson, Ottawa
10. Martin, J.W., and J.R. Parrish, 2000. Lark Sparrow (Chondestes grammacus). In The Birds of North America, No. 488 (A. Poole and F. Gill, eds.). The Birds of North America, Inc., Philadelphia.

11. Potter, L.B. 1923. Notes on birds in southwest Saskatchewan. Condor 25:101-102.

12. Potter, L.B. 1943. Bird notes from south-western Saskatchewan. Canadian Field-Naturalist 58:66-67.

13. Renaud, W.E., and D.E. Renaud. 1975. Birds of the Rosetown-Biggar district, Saskatchewan. Special Publication 9, Saskatchewan Natural History Society, Regina

14. Roy, J.F. 1995. Birds of the Elbow. Special Publication 21, Saskatchewan Natural History Society, Regina

15. Street, M.G. 1965. Lark Sparrow breeding at Nipawin. Blue Jay 23:26-27.

16. Walley, W.J. 1985. Breeding range extension of the Lark Sparrow into westcentral Manitoba. Blue Jay 43:18-24.

\section{ADDENDUM: THE GREAT BUFFLEHEAD CRASH ${ }^{1}$}

JAMES K. FINLEY, 10232 Summerset Place, Sidney, BC V8L 4X2

After dealing with some exasperating details, I printed a final copy of "The Great Bufflehead Crash" ${ }^{1}$ and sent it off to the editors of Blue Jay. I also printed a copy for my Foam Lake correspondents, and mailed it on October $31^{\text {st }}$. Next day, I left on a trip into the interior of B.C. to watch - what else - Buffleheads: When I returned a week later, some details and buffleheads had returned to haunt me.

My return to the coast nearly coincided with: a) the sixtieth anniversary of the Great Bufflehead Crash (November $4-5^{\text {th }}$ ), b) the first 